\title{
MICROBIOLOGICAL STUDY OF SOME COOKED CHICKEN PRODUCTS AT AL-TAIF, KSA
}

\author{
EMAN M. SHARAF* and SHERIFA M. SABRA ${ }^{* *}$ \\ ${ }^{*}$ Associated prof., Consultant, Ass. Prof ${ }^{* *}$. \\ Branch of Microbiology, Science Collage, Taif University, KSA \\ Corresponding author Dr. Sherifa Sabra EM atheer1800@yahoo.com 00966502595358
}

\section{ABSTRACT}

Receved: 9/4/2012

Accepted at: 16/7/2012
This Study was carried out on 40 random samples of cooked chicken products Luncheon and Shawerma (20 of each). They were collected from different supermarkets at Al-Taif Governorate. The results revealed that the mean value of total Aerobic plate, were Aerobic plate, Enterobacteriacae spp., E.coli, Staph.spp. (other than Staph.aureus), Staph.aureus, Moulds and Yeasts count in Luncheon $\left(1 \times 10^{4}, 3 \times 10^{4}, 4 \times 10,4 \times 10^{2}, 1 \times 10^{3}, 8 \times 10^{2}, 4 \times 10^{3}\right.$ respectively) while in Shawerma were $\left(1 \times 10^{5}, 2 \times 10^{4}, 4 \times 10^{2}, 6 \times 10^{3}, 00,6 \times 10^{4}, 5.2 \times 10^{5}\right.$ respectively). The isolation percentages of Staph.aureus, E.coli, Moulds, Yeasts in Luncheon were $(10 \%, 25 \%, 50 \%$ and $65 \%$ respectively) while in Shawerma were $(00 \%$, $20 \%, 65 \%$ and $70 \%$ respectively).

Key words: Luncheon, Shawerma, Enterobacteriacae

\section{INTRODUCTION}

Chicken and chicken products provide animal protein of high biological value for consumers at all ages, where they contain all the essential amino acids required for human growth, higher proportion of unsaturated fatty acids and less in cholesterol value. Moreover, poultry meat is good source of different types of vitamins as niacin, riboflavin, thiamine and ascorbic acid as well as Sodium, Calcium, Iron, Phosphorus, Sulpher and Iodine (Ahmed and Abou Hussein, 2007).

Staph.spp., E.coli, and Salmonella spp., on meat, sea foods, vegetable ingredients, chicken Shawarmas, raw and cooked foods, raw chicken, beef burger sandwiches, ready-to eat salad vegetables, commercial mayonnaise, frozen chicken, poultry products and on the hands of food workers (Kaker and Udipi, 2002).

In processing plants, contamination of poultry meat products can occur throughout processing, packaging and storage until the product is sufficiently cooked and consumed. Heavy bacterial loads enter the processing operations with the living birds and these bacteria can be disseminated throughout the plant during processing. Diseases can also result when these products not properly cooked and post-processing contaminated (Zhang et al., 2001).

Staph aureus is the most prevalent contagious pathogens, which rapidly and easily transmitted, as well as it cause a zoonotic disease which transmitted to human being, due to the permanent interchange of Staph.aureus from human to animals the reverse occurs as a result of the close ecological relations between man, environment and animals (Forbes et al., 2002).

Poultry are known to harbor a large number of bacteria that are pathogenic to human being. Typically, these occur in low sanitation levels, and only pose a threat to the consumer if the product is not handled in a safe manner, therefore, the production, transportation and sale of meat products must be performed with the almost care and preferably be subjected to hazard analysis critical control point (HACCP) evaluation, to prevent the presentation of any undue hazard (Madden, 1994).

Therefore, the present study was planned out to secure Aerobic plate count, Enterobacteriaceae spp., E coli, Staph.spp., Staph.aureus and total Moulds and Yeasts counts.

\section{MATERIALS and METHODS}

- Collection of samples: A total of 40 random samples of cooked chicken products represented by chicken Shawerma and Luncheon (20 of each) were collected from different supermarkets at Al-Taif, KSA. Weight of each sample was $100 \mathrm{~g}$ and aseptically transferred, without delay, in an insulated ice box to the laboratory and then subjected to the following examinations.

- Bacteriological examination (A.P.H.A., 1992): Twenty five grams of the examined samples were homogenized with $225 \mathrm{ml}$. of sterile buffered peptone water $(0.1 \%)$ to give a dilution of $\left(10^{-1}\right)$. One $\mathrm{ml}$ of the clear homogenate was mixed with 
$9 \mathrm{ml}$ of buffered peptone water $(0.1 \%)$, and then decimal serial dilutions were prepared.

- Determination of Aerobic Plate Count (APC) (Swanson et al., 1992): Nutrient agar (Oxoid CM 485 ) plates were dried, then $0.1 \mathrm{ml}$ quantities of each dilution was spread over the medium using sterile glass spreader in backward and forward movement, while rotating the plates then the plates were covered and left to dry for a period of $1-2 \mathrm{hrs}$ before being inverted and incubated at $30^{\circ} \mathrm{c}$ for $48 \mathrm{hrs}$. Colonies were counted in countable plates (30-300) to get the count in $1 \mathrm{ml}$ of the homogenate, the total aerobic bacteria/gram was calculated.

- Determination of Enterobacteriaceae spp. Count (ICMSF, 1978): $T$ surface plate technique was applied using Violet red bile glucose agar ( Oxoid $\mathrm{CM} 485$ ). Inoculated plates were incubated at $37^{\circ} \mathrm{c}$ for $24 \mathrm{hrs}$. All purple colonies surrounded by purple zone were counted and the average number of Enterobacteriaceae spp./gram of the sample was calculated and recorded.

- Estimation of E.coli count (MPN) (FAO, 1992): Three tubes of Lauryl Sulphate Tryptose broth containing inverted Durham's tubes were inoculated with $1 \mathrm{ml}$ of the previously prepared homogenate $1: 10$ and 3 tubes of dilution 1:1000 were inoculated, then the (LST) tubes were incubated at $37^{\circ} \mathrm{c}$ for $24-$ $48 \mathrm{hrs}$. Test tubes that showed collected gas in Durham's tubes were recorded after $24 \mathrm{hrs}$, as positive result, the negative tubes were re-incubated for further $24 \mathrm{hrs}$, the positive one recorded. A loopful from each gas- negative tube of (LST) was transferred to E.coli broth $(E C)$. The inoculated tubes were incubated at $45.5^{\circ} \mathrm{c}$ in water bath for $24-$ 48hrs. Positive tubes showed gas production density in Durham's tubes were recorded and the bacterial density was estimated according to the MNP table.

- Dtermination of Staph.spp. count (FAO, 1992): Accurately, $0.1 \mathrm{ml}$ from each of previously prepared serial dilutions was spread over a duplicated plate of Baird Parker agar using a sterile bented glass spreader. The inoculated control plates were incubated at $37^{\circ} \mathrm{c}$ for $48 \mathrm{hrs}$. Shiny black colonies were enumerated and the total Staph.spp. count/g was calculated. The colonies appear as black, shiny colonies with narrow white margin and surrounded by a clear zone were enumerated and Staph.aureus count/g was calculated. The suspected colonies of Staph aureus were stabbed into semisolid agar tubes for further biochemical identification according to (ICMSF, 1978).

- Mycological examination: Total Moulds and Yeasts counts (Cruickshank et al., 1975): From each of the previously prepared serial dilutions $0.1 \mathrm{ml}$ was inoculated into duplicate Petri dishes of Sabouraud Dextrose agar medium supplemented with Chloramphenicol and Tetracycline $(100 \mathrm{mg} / \mathrm{L}$ of each) (Koburgur and Farahat, 1975). The inoculated plates were incubated at $25^{\circ} \mathrm{c}$ and examined daily for "star like shape" colonies. The total Moulds and Yeasts count/g was calculated and were recorded.

\section{RESULTS}

Table 1: Mean count of bacteria isolated from chicken meat products in Taif.

\begin{tabular}{lccccccc}
\hline $\begin{array}{l}\text { Samples } \\
\text { Count }\end{array}$ & $\begin{array}{c}\text { Aerobic } \\
\text { plate count }\end{array}$ & $\begin{array}{c}\text { Enterobacteriacae } \\
\text { count }\end{array}$ & $\begin{array}{c}\text { E.coli } \\
\text { count }\end{array}$ & $\begin{array}{c}\text { Staph.spp. } \\
\text { count }\end{array}$ & $\begin{array}{c}\text { Staph.aureus } \\
\text { count }\end{array}$ & $\begin{array}{c}\text { Moulds } \\
\text { count }\end{array}$ & $\begin{array}{c}\text { Yeasts } \\
\text { count }\end{array}$ \\
\hline Luncheon & $1 \times 10^{4}$ & $3 \times 10^{4}$ & $4 \times 10$ & $4 \times 10^{2}$ & $1 \times 10^{3}$ & $8 \times 10^{2}$ & $4 \times 10^{3}$ \\
\hline Shawerma & $1 \times 10^{5}$ & $2 \times 10^{4}$ & $4 \times 10^{2}$ & $6 \times 10^{3}$ & 00 & $6 \times 10^{4}$ & $5 \times 10^{5}$ \\
\hline
\end{tabular}

Table 2: Incidence of Staph.aureus, E.coli, Moulds and Yeasts isolated from chicken meat products in Taif (Total number $=20)$

\begin{tabular}{|c|c|c|c|c|c|c|c|c|}
\hline \multirow[t]{2}{*}{ Samples } & \multicolumn{2}{|c|}{ Staph.aureus } & \multicolumn{2}{|c|}{ E.coli } & \multicolumn{2}{|c|}{ Moulds } & \multicolumn{2}{|c|}{ Yeasts } \\
\hline & $\begin{array}{l}\text { NO. of } \\
\text { positive } \\
\text { samples }\end{array}$ & & $\begin{array}{l}\text { NO. of } \\
\text { positive } \\
\text { samples }\end{array}$ & $\%$ & $\begin{array}{l}\text { NO. of } \\
\text { positive } \\
\text { samples }\end{array}$ & $\%$ & $\begin{array}{l}\text { NO. of } \\
\text { positive } \\
\text { samples }\end{array}$ & $\%$ \\
\hline Luncheon & 2 & $10 \%$ & 5 & $25 \%$ & 10 & $50 \%$ & 13 & $65 \%$ \\
\hline Shawerma & 00 & $00 \%$ & 4 & $20 \%$ & 13 & $65 \%$ & 14 & $70 \%$ \\
\hline
\end{tabular}




\section{DISCUSSION}

Microbiological examination is a sensitive measure collectively verifying the quality of raw material used the perfection of processing, as well as the proper storage of the results. Tables $1 \& 2$ revealed that the APC of examined cooked chicken Product samples was $1 \times 10^{4}$ for Luncheon and $1 \times 10^{5}$ for Shawerma, the recorded results were nearly similar to those obtained by Capital et al. (2002); Hashim (2003); Essa et al. (2004).

While Enterobacteriacae count was $3 \times 10^{4}$ for Luncheon and $2 \times 10^{4}$ for Shawerma, similar results were reported by Essa et al. (2004); Goksoy et al. (2004). E.coli count for Luncheon was $4 \times 10$ and $4 \times 10^{2}$ for Shawerma, the frequency distribution of E.coli of positive samples of both Luncheon and Shawerma was $25 \%$ and $20 \%$ respectively. Lower results were recorded by Hefnawy and Moustafa (1990) (10\% E.coli of ready- to eat products), Soriano et al. (2000).

Staph.spp. count was $4 \times 10^{2}$ for Luncheon and $6 \times 10^{3}$ for Shawerma, the frequency distribution of Staph.spp. count of positive samples of both Luncheon and Shawerma was $80 \%$ and $70 \%$, high incidence of Staph.spp. organisms in chicken products indicative of unacceptable level of contamination during handling (Lotfi et al., 1990), these obtained results were agree with Kaker and Udipi (2002); Gad (2004).

The epidemiological data of Staph.aureus showed that continued to be a major cause of food borne intoxication and its presence in food constitute an important problem for food processors, food service workers and consumers. Tables 1\&2 showed low incidence of Staph.aureus 2 (10\%) for Luncheon and $00(00 \%)$ for Shawerma, Staph.aureus count was $1 \times 10^{3}$ for Luncheon and 00 for Shawerma. The obtained results nearly agree with Gad (2004), while relatively higher results were obtained by Essa et al. (2004), the low incidence of Staph.aureus in examined samples may be attributed to exposure of those products to high temperature during processing (Ahmed, 2004).

Chicken Luncheon was the most contaminated product and this may due to inadequate cooking, post processing contamination, cross contamination through slicing machines or cutting knives used in food serving centers in addition to raw material and spices introduced during manufacture (Varnam and Evans, 1991).

Moulds and Yeasts contamination of chicken products may lead to their spoilage, in addition to some Moulds spp. Which were incriminated in human mycosis (Mossel, 1975), in this study, Moulds count was $8 \times 10$ ${ }^{2}$ for Luncheon and $6 \times 10^{4}$ for Shawerma, the positive product samples were $50 \%$ for Luncheon and $65 \%$ for Shawerma. The obtained results were similar to Edris et al. (1992); Gad (2004). Yeasts count for luncheon was $4.3 \times 10^{3}$ and $5.2 \times 10^{5}$ for shawerma; the positive product samples were $65 \%$ for Luncheon and $70 \%$ for Shawerma. The obtained results were agreed with Ahmed (2004). Moulds and yeasts contamination usually occurred due to handling, deboning, processing, packing, and washing with polluted water, may due to dust, flies, air, workers, equipments and fluctuation of temperature during transportation and storage (Refaie et al., 1991; Farghaly, 1998).

Results of our study are indicative for contamination and inadequate hygienic conditions in production and processing of chicken meat products. Finally to improve the hygienic quality of chicken meat products to be safe for human consumption the contamination must be reduced by implementing satisfactory manufacturing practices and effectively training plant workers in hygiene, safety and quality assurance, application of strict hygienic measures during handling preparation and serving the products.

\section{REFERENCES}

Ahmed, A. (2004): Trials for inhibition of some food poisoning microorganisms in meat products. Ph.D. Thesis, Meat Hygiene, Fac.Vet. Med.,Cairo Univ.

Ahmed, F. (2004): Studies on cooked meat and chicken products. Ph.D. Thesis, Meat Hygiene Fac. Vet. Med., Zagazig Univ. (Banha Branch).

Ahmed, R. and Abou Hussein, M. (2007): Detection of food mediated pathogens in some meat and chicken products by using recent techniques. Ph. D. Thesis, meat hygiene, Fac. Vet. Med., Banha Univ.

APHA (1992): Compendium of methods for microbiological examination of foods. American Public Health Association, Washington, D.C., USA. 105 (4): 100-101.

Capital, R.; Alonso-Calleja, C. and Cariciafernandez, M. (2002): Methods to detect the occurrence of various indicator bacteria on the surface of retial poultry in Spain. J. Food Sci. 67.

Cruickshank, R.; Duguid, J.; Marmion, B. and Swain, R. (1975): Medical microbiology. The practice of medical microbiology. V11, $12^{\mathrm{th}}$ Ed. Churchil. Living Stone, Edinburgh, Chapter 5.

Edris, M.; Abd El-Rahman, M. and Mousa, M. (1992): Microbial evaluation of some retailed cut up chicken meat products. Benha Vet. Med. J., 3:154-166.

Essa, H,; Maker, N,; Sohair, A, and Hussein, Z, (2004): Bacteriological evaluation of chicken luncheon in Assuit City. Assuit Vet. Med. J. 50:64-71.

FAO (1992): Manual of food quality control. Part (4). Microbiological analysis, United Nations, Rome. Pp:531-540.

Farghaly, R. (1998): Some studies on the afla-toxin producing aspergilli in meat cold stores. Assuit Vet. Med. J. 111-120. 
Forbes, B.; Sahm, D. and Weissfield, A. (1998): "Diagnostic Microbiology" 10 th ed. Mosby Inc. pp:11830.

Gad, M. (2004): Microbiological evaluation of poultry meat and its products. M.V.Sc. (Meat Hygiene), Fact. Vet. Sadat Univ.

Goksoy, E.; Kirhan, S. and Kok, F. (2004): Microbiological survey of a south African.

Hashim, E. (2003): Aerobic and anaerobic enterotoxigenic bacteria in ready - to- eat food. Ph.D. Thesis, Meat Hygiene, Fac.Vet. Med., Zagazig Univ. (Banha Branch).

Hefnawy, Y. and Moustafa, S. (1990): Quality evaluation of ready- to- eat poultry in Assuit city. Assuit Vet. Med. J 23: 119-125.

ICMSF (1978): Microorganisms in foods. 1: Their significance and methods for enumeration. $2^{\text {th }}$ ed. Univ. of Toronto Press, Toronto, Qntario, Canada.Chapter 3.

Kakar, D. and Udipi, S. (2002): Microbiological quality of ready- to- eat meat and meat products solid in Mubi city. J. Food Sci. and Technol., 39:299-303.

Koburger, J. and Farahat, B. (1975): Fungi in foods. Comparison of media to enumerate yeast and mould. J. Milk and Food Technol. 38:455-468.

Lotfi, A.; Youssef, H.; Hefnawy, Y.; El-Timawy, A. and Nasser, A. (1990): Sanitary status of meat meals in Assuit Univ. Hospitals. Assuit Vet. Med. J. 23:126-130.
Madden, N. (1994): Microbial hazards in animal products. Proceeding of the Nutrition Society, 53:309.

Mossel, A. (1982): Occurrence of, prevention and monitoring of microbial quality loss of food and dairy products. Crit. Rev. Environ. Control, 5:1.

Refaie, M.; Mansour, N.; El-Nagga, A. and AbedelAziz, A. (1991): Fungal flora in.

Sawanson, K.; Busta, F.; Peterson, E. and Johnson, M. (1992): Colony count methods. Pp:75-96. in Vanderzant, C. and Splittoesser, O (Eds). Compendium of methods for microbiological examination of foods. American Public Health Association, Washington, D.C., USA. 105:100-101.

Soriano, J.; Blesa, D.; Rico, H. and Manes, J. (2002): Incidence of Staph.aureus ducts. proin meals from cafeterias. J. of Food Safety, 22: 134140.

Todd, E. (1977): Food- borne disease in Canada1974- Annual summary. J. Food Prot. 40:493-498.

Varnam, P. and Evans, M. (1991): Food borne pathogens. An illustrated textbook. Wolf publishing Ltd., New York, App., 101-108.

Zhang, L.; Davis, M. and Conner, D. (2001): Poultryborne pathogens: plant considerations. Poultry meat processing chap.9. ISBN 0.

\section{دراسة ميكروبيولوجية لبعض منتجات الاجاج المطبوخ في الطائف بالمملكة العربية السعودية إيمان محمود شرف ، شريفة مصطفى صبر}

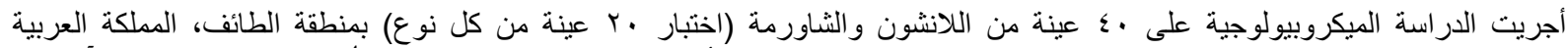

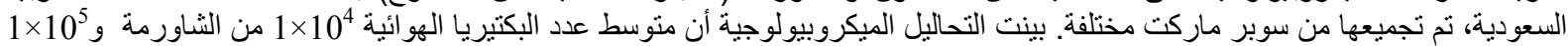

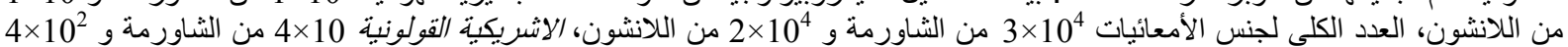

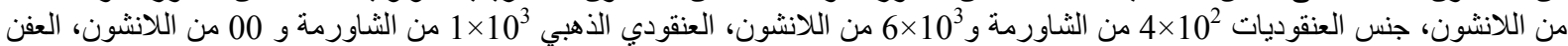

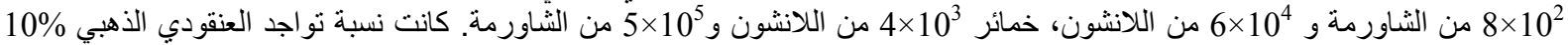

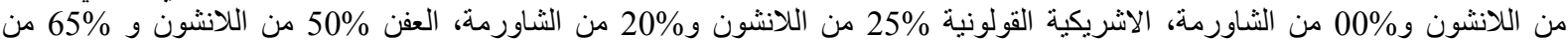

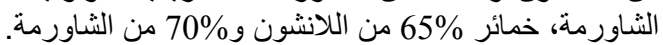

